\title{
Serpin B9
}

National Cancer Institute

\section{Source}

National Cancer Institute. Serpin B9. NCI Thesaurus. Code C104580.

Serpin B9 (376 aa, $\sim 42 \mathrm{kDa}$ ) is encoded by the human SERPINB9 gene. This protein plays a role in the inhibition of granzyme $B$. 